\title{
A CROSS-CULTURAL ANALYSIS IN PREDICTING 2X2 ACHIEVEMENT GOALS IN PHYSICAL EDUCATION BASED ON SOCIAL GOALS, PERCEIVED LOCUS OF CAUSALITY AND CAUSAL ATTRIBUTION
}

\author{
Antonio BAENA EXTREMERA ${ }^{1}$, Francisco RUIZ-JUAN ${ }^{1}$, Antonio GRANERO-GALLEGOS ${ }^{2}$ \\ ${ }^{1}$ Faculty of Sports Science, University of Murcia \\ Santiago de la Ribera street, s/n, 30720 Murcia, Spain \\ E-mail: abaenaextrem@um.es \\ ${ }^{2}$ Consejery of Education. Junta of Andalussia. Spain
}

\begin{abstract}
This research is based on the Achievement Goal Theory, the Self-Determination Theory and the Theory of Causal Attribution. The aim of this study was to determine how social goals, perceived locus of causality and causal attribution, predict students' goal orientations in physical education and in different countries and cultures. The sample consisted of 2168 students (11 to 16 years), 423 from Costa Rica, 408 from Mexico and 1052 from Spain. Fieldwork was conducted in 2011 using the following instruments: the scale of 2x2 Achievement Goals, Social Goals Scale in Physical Education, Perceived Locus of Causality questionnaire and Causal Attribution. We evaluated the factor structure of each instrument with confirmatory analysis and hierarchical linear regression. The importance of the study lies on the predictive analysis of the trend in the three countries towards PE Achievement Goals, emphasizing the role of internal causal attribution as a predictor of the approximation of achievement goals.
\end{abstract}

Key words: motivation, teenager, responsibility, performance, mastery

\section{Introduction}

Physical Education aims at promoting teenagers' commitment to and support of regular leisure time physical and sports activity. Physical Education (PE) provides students with opportunities to improve their relationships, cooperation and level of responsibility, as well as their skills. Therefore, it is important to understand the different personal and situational factors affecting teenage students' motivation and to deepen the analysis of their will to succeed, especially if we bear in mind that motivational goals are pre- dictors of behavioral persistence (Vallerand \& Bissonnette, 1992) and that other authors such as Telama et al. (2005) have stated that the practice of physical activity at an early age is significantly linked to the practice of physical activity in adulthood.

In this regard, the Achievement Goal Theory, a social-cognitive theory, has been one of the most widely used in recent years in the field of motivation studies in achievement contexts in the area of education (Chen, 2001), in order to analyze how students acquire, represent and use knowledge. When this theory is applied to the academic field, the dichotomous model explains that stu-

DOI: $10.21909 / \mathrm{sp} .2016 .01 .708$ 
dents can have task oriented mastery goals (based on efforts and improvement in the execution of tasks) or ego oriented performance goals (the aim is to obtain results and to show superiority in relation to other students) (Ames, 1992; Nicholls, 1989). The 2x2 model(Elliot, 1999; Elliot \& McGregor, 2001) was created based on these ideas; this model holds that the central element of achievement goals is competition and that the value of this has to be taken into account rather than only its form. Therefore, this model includes four potential goals: mastery-approach goals (absolute and intrapersonal definition of competition and positive valence), performance-approach goals (normative definition and positive valence), mastery-avoidance goals (absolute and intrapersonal definition of competition and negative valence), and performance-avoidance goals (normative definition and negative valence). This instrument has been adapted to PE (Guan, Xiang, McBride, \& Bruene, 2006; Wang, Biddle, \& Elliot, 2007) and these studies have shown positive and significant correlation across the four achievement goals. Moreno, González-Cutre and Sicilia (2008) carried out a $2 \times 2$ achievement goals study with 813 students aged 11-16 years old and found that the promotion of mastery-oriented climates probably continues to lead to positive adaptation to physical activity. However, Wang et al. (2007) noted that combined profiles including both high performance goals and high mastery goals spark self-determined motivation in students as well as high perception of competition, good inter-student relationships, joy, effort, practice of physical education, and low levels of boredom and demotivation. However, some studies have found that task orientation is associated with more positive affective and be- havioral patterns as opposed to ego orientation, which is related to less adaptive patterns. Furthermore, task orientation has been found to be associated with higher levels of sports practice outside the school (Cervelló $\&$ Santos-Rosa, 2000). This relationship is negative in the case of ego orientation.

If we take into account all the individual and environmental agents and factors which can affect teenage students' success in this educational stage, it is interesting to analyze social goals when studying achievement goals. Social goals are cognitive representations of the desired results at the social level and its consequences depend on the type of goals selected. Thus, students can also feel competent and successful in spheres other than the academic context (Urdan \& Maehr, 1995); they can, for instance, have a social skill, which allows them to interact with the rest of the students. Following Guan, McBride and Xiang (2006), we have described two social goals in PE (even though there are more, see e.g., Dweck, 1986): the responsibility goal and the relationship goal. The former refers to the willingness to follow the different rules and social roles established in class (Wentzel, 1991); students try to behave responsibly and feel successful when they achieve that goal. The latter reflects a need to establish good relationships and friendship with classmates (Ryan, Hicks, \& Midgley, 1997).

In recent times, Self-Determination Theory (SDT) (Deci \& Ryan, 1985, 2000; Ryan \& Deci, 2000) has been widely used in motivation studies carried out in the field of Physical Education. This theory is understood as a continuum on which different levels of selfdetermination are established: the highest degree is seen in an intrinsically motivated person; extrinsically motivated people show 
a lower level and demotivated people are those showing the lowest level of self-determination. In terms of extrinsic motivation, it is worth noting that it refers to behaviors disclosed due to instrumental reasons or external sources and according to Deci and Ryan $(1985,2000)$, we can differentiate the following types of regulation in descending order according to level of self-determination: integrated, identified, introjected and external regulation. Integrated regulation would be the case of students who fully involve themselves in PE classes because physical activity is part of their lifestyle. Identified regulation reflects practice carried out by students because they are aware of the importance and the benefits of Physical Education. As to introjected regulation, it refers to students who actively participate in class, as otherwise they would feel guilty and bad about themselves. Finally, external regulation is associated with those students who participate in class just because they have to; educational institutions stipulate this and failing to join in would imply punishment. The literature includes a great number of PE studies based on this theory (see e.g., Méndez-Giménez, Fernández-Río, Cecchini, \& González, 2013).

Another theory worth highlighting when it comes to explaining students' motivation in class is Weiner's Attribution Theory (Weiner 1986, 1995). According to Weiner, within achievement contexts the model starts with a result which, depending on whether subjects regard it as success or failure produces a positive or negative feeling (Navas, Holgado, Soriano, \& Sampascual, 2008). Therefore, students' success in PE classes can be explained in different ways: students' ability, efforts, task difficulty and luck. Thus, associations of causes and events are made at all times when execution contexts are studied and sports and academic contexts can serve as examples (Malico, Rosado, Cabrita, $\&$ Lancho, 2010). When a student finds this cause, they place it on a causal dimension, which is in turn highly related to affective reactions and expectations of success. Thus, the literature shows that one of the significant factors in school performance is the importance students attach to their academic success or failure (Mascarenhas, Almeida, \& Barca 2005). However, studies carried out in the sports context have been scant (Malico et al., 2010), and even more so in the PE field.

In view of the above, the aim of this study is to find out how social goals, the perceived causality locus and causal attribution predict goal orientations in PE students in different countries and cultures. As hypothesis, we have estimated the role of internal causal attribution as a predictor of the approximation of achievement goals and the sample of three countries.

\section{Method}

\section{Participants}

2168 students in their first year of secondary education participated in this study; they were randomly selected to take part in a longitudinal study in Costa Rica (423), Mexico (408) and Spain (1337), 1052 were male (50.4\%), 1037 female (49.6\%) and 79 students who did not specify gender. $86.6 \%$ were from state schools and $13.4 \%$ charter schools. The age range was 11 to 16 years old $(M=12.49$; $S D=.81)$ with the median age for boys being $12.53(S D=.87)$ and 12.44 for girls $(S D=.74)$. The fieldwork was carried out between February and June, 2011. 


\section{Procedure}

We asked schools for permission to carry out research in a letter explaining the aims of the study and how it would be carried out; a model of the instrument to be used was attached. This instrument was self-administered and it was applied on a large scale; it was filled in anonymously during a school day, with prior agreement and training given by the evaluators. Subjects were briefed on the object of the study, its voluntary nature and on the absolute confidentiality for the answers and data management. It was further explained to them that there were no correct or incorrect answers and they were asked to reply with maximum sincerity and honesty. Only students whose parents and tutors had given informed consent participated in the study. The Bioethics Committee of the Universidad de Murcia approved the studied. The data presented in this paper corresponds to the first data collection of the longitudinal study and establishes its baseline.

\section{Instruments}

$2 \times 2$ Achievement Goals adapted to PE by Moreno et al. (2008), Spanish version by Wang et al. (2007), created to measure achievement goal orientations in PE students. The original instrument includes 12 items and 4 subscales (three items per factor): mastery-approach, mastery-avoidance, performance-approach and performanceavoidance. The header read: "In my Physical Education class...”. The answers were collected on a Likert scale from 1 (totally disagree) to 7 (totally agree). The internal consistency values in the original subscales were: mastery-approach $(\alpha=.70)$, masteryavoidance $(\alpha=.71)$, performance-approach $(\alpha=.72)$ and performance-avoidance $(\alpha=$ $.67)$.

Metas Sociales en Educación Física by Moreno et al. (2008), a Spanish version of Social Goal Scale-Physical Education by Guan et al. (2006), created to measure responsibility through five items and the relationship goal through six items. The header read: "In my Physical Education class..." The answers were collected on a Likert scale from 1 (totally disagree) to 7 (totally agree). The internal consistency values in the original subscales were: responsibility $(\alpha=.73)$ and relationship $(\alpha=.75)$.

Locus Percibido de Causalidad by Moreno, González-Cutre and Chillón (2009), a Spanish version of Perceived Locus of Causality Scale by Goudas, Biddle and Fox (1994), created to measure the different forms of motivation established by Self-Determination Theory in the context of Physical Education: intrinsic motivation, external regulation, introjected regulation, identified regulation and amotivation. It includes 20 items distributed on the seven subscales previously mentioned. The header read: "I participate in this Physical Education class..." Answers were scored on a 7 point Likert scale from 1 (totally disagree) to 7 (totally agree). This instrument allow the estimation of a global index of self-determined motivation in PE classes by combining the different subscales: Self-Determination Index $(\mathrm{SDI}))=(2 \mathrm{x}$ intrinsic motivation + identified regulation) [(introjected regulation + external regulation) / $2+2 x$ demotivation] (Vallerand \& Rousseau, 2001). The internal consistency values of the original subscales were: intrinsic motivation $(a=.75)$, external regulation ( $\alpha=.70)$, introjected regulation $(\alpha=.61)$, 
identified regulation $(\alpha=.74)$ and amotivation $(\alpha=.76)$.

Causal Attribution by Navas et al. (2008), created to estimate students' causal attributions in PE classes. It includes 7 items distributed on two scales measuring internal attribution (4 items) and external attribution ( 3 items). Subjects pointed out their level of agreement with the items and their answers were collected on a Likert scale from 1 (totally disagree) to 7 (totally agree). The internal consistency values of the original subscales were: intrinsic attribution $(\alpha=$ $.68)$, external attribution $(\alpha=.65)$.

\section{Instrument Psychometric Properties}

Psychometric properties were estimated following the analysis procedure set up by Carretero-Dios and Pérez (2005). None of the items were eliminated post analysis as they all satisfied the requirements $(\geq .30$ value in item-total corrected correlation coefficient, $>1$ standard deviation; all the answer op- tions were used). The homogeneity analysis showed no item overlapping across theoretical dimensions on both questionnaires. The asymmetry and kurtosis indices were close to zero and $<2.0$ as recommended by Bollen and Long (1994), which indicates similarity to the univariate standard curve. The factor validity of the four instruments was analyzed with CFA Bootstrapping and the maximum likelihood procedure, an estimation of structural equation models, which assumes normal univariate distribution and a continuous scale given that the bulk of the data lack multivariate standardization, which violates one of the basic rules of CFA.

The model's fit to the data was assessed by means of combining absolute and relative fit indices. The four scales show correct values, which allow for establishing an acceptable fit to the original model (Hoyle, 1995; Hu \& Bentler, 1999; Kline, 1998) as seen in the results obtained. The standardized relation coefficients of the latent variable with each of the items ranged between .64 and

Table 1 Model fit indices

\begin{tabular}{|c|c|c|c|c|c|c|c|}
\hline & & $\chi^{2} / \mathrm{df}$ & TLI & IFI & CFI & RMSEA & SRMR \\
\hline \multirow{4}{*}{$\begin{array}{l}\text { Costa Rica } \\
(n=360)\end{array}$} & 2x2 Achievement Goals & 2.88 & .97 & .98 & .98 & .06 & .02 \\
\hline & $\begin{array}{l}\text { Social Goal Scale-Physical Education } \\
\text { (SGSPE) }\end{array}$ & 2.70 & .99 & .98 & .98 & .06 & .02 \\
\hline & Perceived Locus of Causality (PLOC) & 3.08 & .96 & .95 & .96 & .07 & .04 \\
\hline & Causal Attribution & 4.82 & .97 & .94 & .97 & .07 & .04 \\
\hline \multirow{4}{*}{$\begin{array}{l}\text { Mexico } \\
(n=389)\end{array}$} & $2 \times 2$ Achievement Goals & 4.22 & .92 & .94 & .94 & .08 & .04 \\
\hline & $\begin{array}{l}\text { Social Goal Scale-Physical Education } \\
\text { (SGSPE) }\end{array}$ & 4.07 & .96 & .94 & .95 & .07. & .03 \\
\hline & Perceived Locus of Causality (PLOC) & 4.27 & .91 & .90 & .91 & .07 & .04 \\
\hline & Causal Attribution & 4.53 & .96 & .94 & .96 & .07 & .04 \\
\hline \multirow{5}{*}{$\begin{array}{l}\text { Spain } \\
(n=1062)\end{array}$} & $2 \times 2$ Achievement Goals & 4.07 & .96 & .97 & .97 & .07 & .03 \\
\hline & $\begin{array}{l}\text { Social Goal Scale-Physical Education } \\
\text { (SGSPE) }\end{array}$ & 4.92 & .99 & .98 & .99 & .06 & .01 \\
\hline & Perceived Locus of Causality (PLOC) & 4.37 & .96 & .96 & .96 & .06 & .04 \\
\hline & Causal Attribution & 4.21 & .96 & .94 & .96 & .07 & .04 \\
\hline & Desirable & $<5$ & $>.9$ & $>.9$ & $>.9$ & $<.08$ & $<.05$ \\
\hline
\end{tabular}


.99; standardized factor loads were $>60$ in all cases and t-value was always $>1.96$, which guarantees convergent validity of all the instruments used in this study (Hair, Black, Babin, \& Anderson, 2009). Table 2 shows Cronbach's alpha coefficients. All the subscales showed satisfactory internal consistency (between $\alpha=.70$ and $\alpha=.95$ ).

\section{Data Analysis}

Item and homogeneity analyses, subscales' correlations (Pearson coefficient), internal consistency (Cronbach's alpha), gender mean differences ( $t$ Student), correlations across all the subscales dimensions and hierarchical linear regression were carried out with SPSS 17.0. The factor structure was as- sessed with AMOS 21.0 confirmatory factor analysis (CFA).

\section{Results}

\section{Descriptive Statistics}

As seen in Table 2, the variance analysis shows statistically significant mean differences $(p<.001)$ in each of the variables analyzed across countries. The results of the Bonferroni homogenous subsets show that three different subsets can be defined for most of the variables corresponding to each country, as reflected in Vílchez (2013). As for goal orientations, the highest scores are in mastery-approach $(M=5.88, S D=1.21$, Mexico) and the lowest are seen in perfor-

Table 2 Alpha coefficient ( $\alpha$ ), mean (M) and standard deviation (SD) for $2 \times 2$ Achievement Goals, Perceived Competition, Social Goal Scale-Physical Education (SGSPE), Perceived Locus of Causality (PLOC) and Causal Attributions. Cross-country differences

\begin{tabular}{|c|c|c|c|c|c|c|c|c|c|c|c|}
\hline \multirow[t]{2}{*}{ Questionnaires' subscales } & \multicolumn{3}{|c|}{$\begin{array}{l}\text { Costa Rica } \\
(n=360)\end{array}$} & \multicolumn{3}{|c|}{$\begin{array}{c}\text { Mexico } \\
(n=389)\end{array}$} & \multicolumn{3}{|c|}{$\begin{array}{c}\text { Spain } \\
(n=1062)\end{array}$} & \multirow[t]{2}{*}{$\mathrm{F}$} & \multirow[t]{2}{*}{ Sig. } \\
\hline & $\alpha$ & $M$ & $S D$ & $\alpha$ & $M$ & $S D$ & $\alpha$ & $M$ & $S D$ & & \\
\hline \multicolumn{12}{|l|}{$2 \times 2$ Achievment goals } \\
\hline Performance-approach & .91 & 4.66 & 1.80 & .88 & 5.11 & 1.66 & .88 & 4.14 & 1.73 & 47.99 & .000 \\
\hline Mastery-approach & .76 & 5.31 & 1.50 & .80 & 5.88 & 1.21 & .79 & 5.43 & 1.39 & 19.46 & .000 \\
\hline Performance-avoidance & .81 & 4.91 & 1.58 & .72 & 5.31 & 1.37 & .71 & 4.59 & 1.53 & 33.76 & .000 \\
\hline Mastery-avoidance & .84 & 4.92 & 1.52 & .76 & 5.17 & 1.39 & .81 & 4.68 & 1.43 & 17.33 & .000 \\
\hline \multicolumn{12}{|l|}{$\begin{array}{l}\text { Social Goals in Physical } \\
\text { Education }\end{array}$} \\
\hline Responsibility & .90 & 5.49 & 1.26 & .89 & 5.84 & 1.17 & .92 & 5.44 & 1.32 & 14.15 & .000 \\
\hline Relationship & .88 & 5.42 & 1.23 & .94 & 5.82 & 1.17 & .93 & 5.48 & 1.28 & 12.64 & .000 \\
\hline \multicolumn{12}{|l|}{ Perceived Locus of Causality } \\
\hline Intrinsic Motivation & .92 & 5.40 & 1.48 & .85 & 5.95 & 1.10 & .90 & 5.36 & 1.36 & 28.43 & .000 \\
\hline Identified Regulation & .79 & 5.33 & 1.34 & .74 & 5.77 & 1.14 & .87 & 5.04 & 1.46 & 40.77 & .000 \\
\hline Introjected regulation & .81 & 5.03 & 1.44 & .77 & 5.55 & 1.23 & .81 & 4.75 & 1.40 & 47.36 & .000 \\
\hline External regulation & .89 & 4.63 & 1.66 & .79 & 5.21 & 1.38 & .79 & 4.39 & 1.48 & 42.06 & .000 \\
\hline Amotivation & .93 & 4.11 & 1.85 & .85 & 4.39 & 1.76 & .91 & 3.37 & 1.72 & 57.40 & .000 \\
\hline IAD PLOC & .95 & 3.04 & 5.25 & .93 & 3.34 & 4.43 & .93 & 4.13 & 5.53 & 7.25 & .001 \\
\hline \multicolumn{12}{|l|}{ Causal Attribution } \\
\hline Internal & .86 & 4.12 & .88 & .77 & 4.32 & .63 & .79 & 3.94 & .81 & 33.73 & .000 \\
\hline External & .72 & 3.54 & 1.06 & .70 & 3.69 & .93 & .76 & 3.17 & .96 & 47.90 & .000 \\
\hline
\end{tabular}


mance-approach $(M=4.14, S D=1.73$, Spain $)$ in all three countries, with small differences amongst variables. Similarly, Mexican students obtain the highest scores in all four subscales, followed by Costa Ricans and Spaniards.

The social goals in PE show high means for the responsibility and relationship variables and they are also very similar across all three countries, Mexican students $(M=$ $5.84, S D=1.17, M=5.82, S D=1.17$, respectively) being slightly above Costa Rican and Spanish students. As to perceived locus of causality, again Mexicans have mean values above those of Costa Ricans and Spaniards in each of the variables but the differences are not significant. An important increase in the means is observed as self-determination levels go up, values for Mexicans ranging from $M=4.39(S D=1.76)$ in amotivation to $M=5.95(S D=1.10)$ in intrinsic motivation. However, Spanish students are the ones showing the highest level of self-determination, $(M=4.13, S D=5.53)$ with significant differences when compared to Costa Ricans $(M=3.04, S D=5.25)$. The internal causal attributions show high means for the three countries, being slightly higher in the case of Mexican students $(M=4.32, S D=.63)$. Internal causal attributions show lower means, Spanish students showing the lowest values $(M=3.17, S D=.96)$.

Relationships of Goal Orientations to Social Goals, Perceived Locus of Causality and Causal Attribution

Table 3 shows that the results of the estimated correlations are very similar across the three countries, and we can see that the correlations amongst the four variables composing goal orientations are high. On the other hand, performance-approach, performance-avoidance and mastery-avoidance have low, moderate and positive correlation with the rest of the variables and mastery-approach does not correlate with amotivation. Furthermore, it is worth noting that external causal attributions show the lowest correlation values.

\section{Multivariate Regression Analysis}

Next, a multivariate linear regression analysis was carried out taking the goal orientations mean scores as dependent variables (performance-approach, mastery-approach performance-avoidance and mastery-avoidance) and each of the social goals, perceived locus of causality and causal attribution variables as predictors. Finally, country was the selection variable. The result of this analysis was a number of solid models, which explained a great part of the variance in each country, between $21 \%$ and $45 \%$.

This analysis allowed for the extraction of the $\mathrm{R}^{2}$ value to explain variance, the Beta value to explain variable prediction, and the $F$ value to find out whether there was a relationship between the selected variables and their significance (Table 4). The models show that in Mexico performance-approach can be significantly predicted by high scores in amotivation and internal attributions (25\% of variance). However, in Costa Rica and Spain this would be predicted by high scores in introjected regulation and external attributions as well and in the case of Costa Rica also in responsibility ( $43 \%$ of variance in Costa Rica and 30\% in Spain). Furthermore, in Costa Rica mastery-approach can be significantly predicted by high scores in responsibility, introjected regulation, identified regulation and internal attributions and by low scores in external regulation $(45 \%$ of vari- 


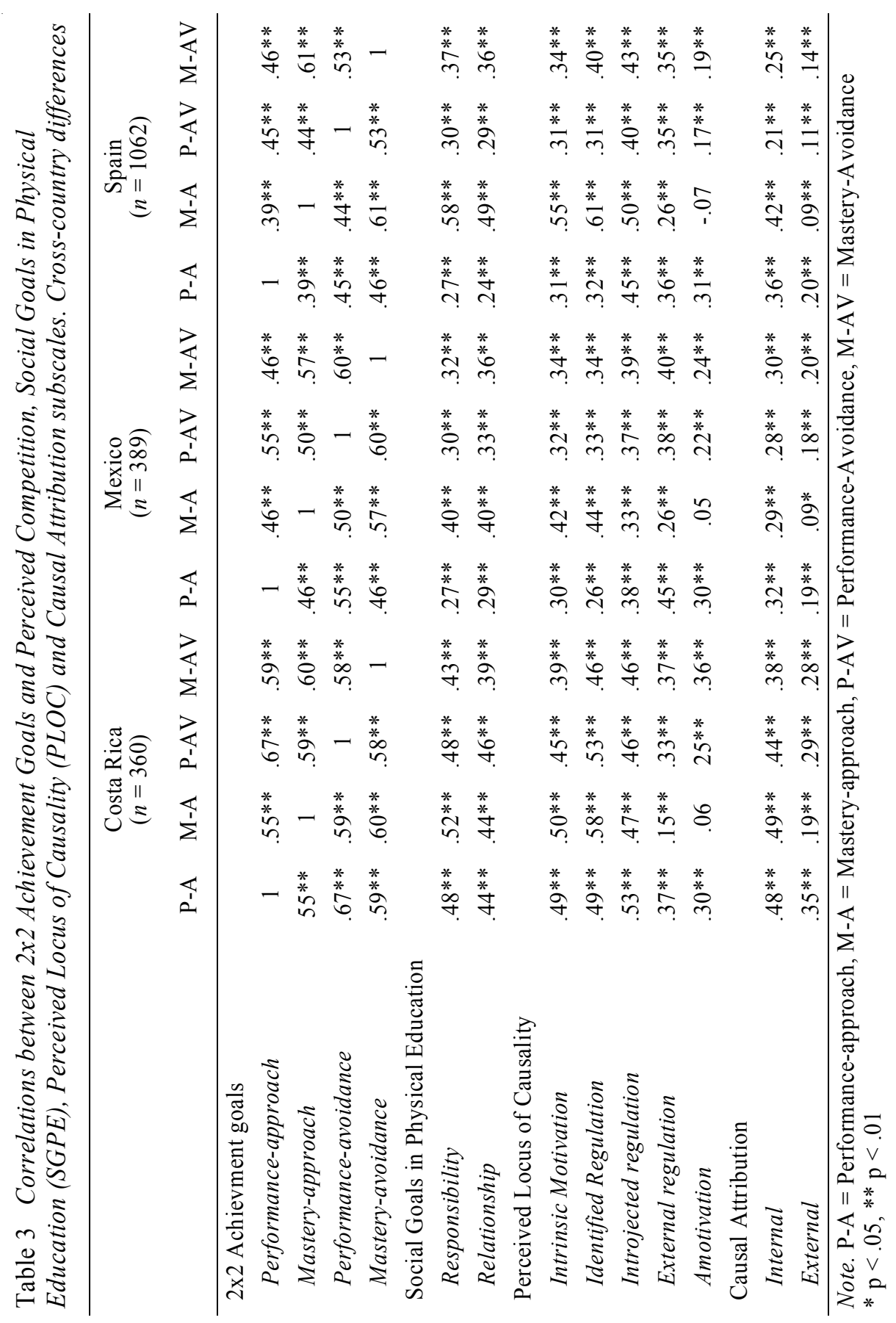




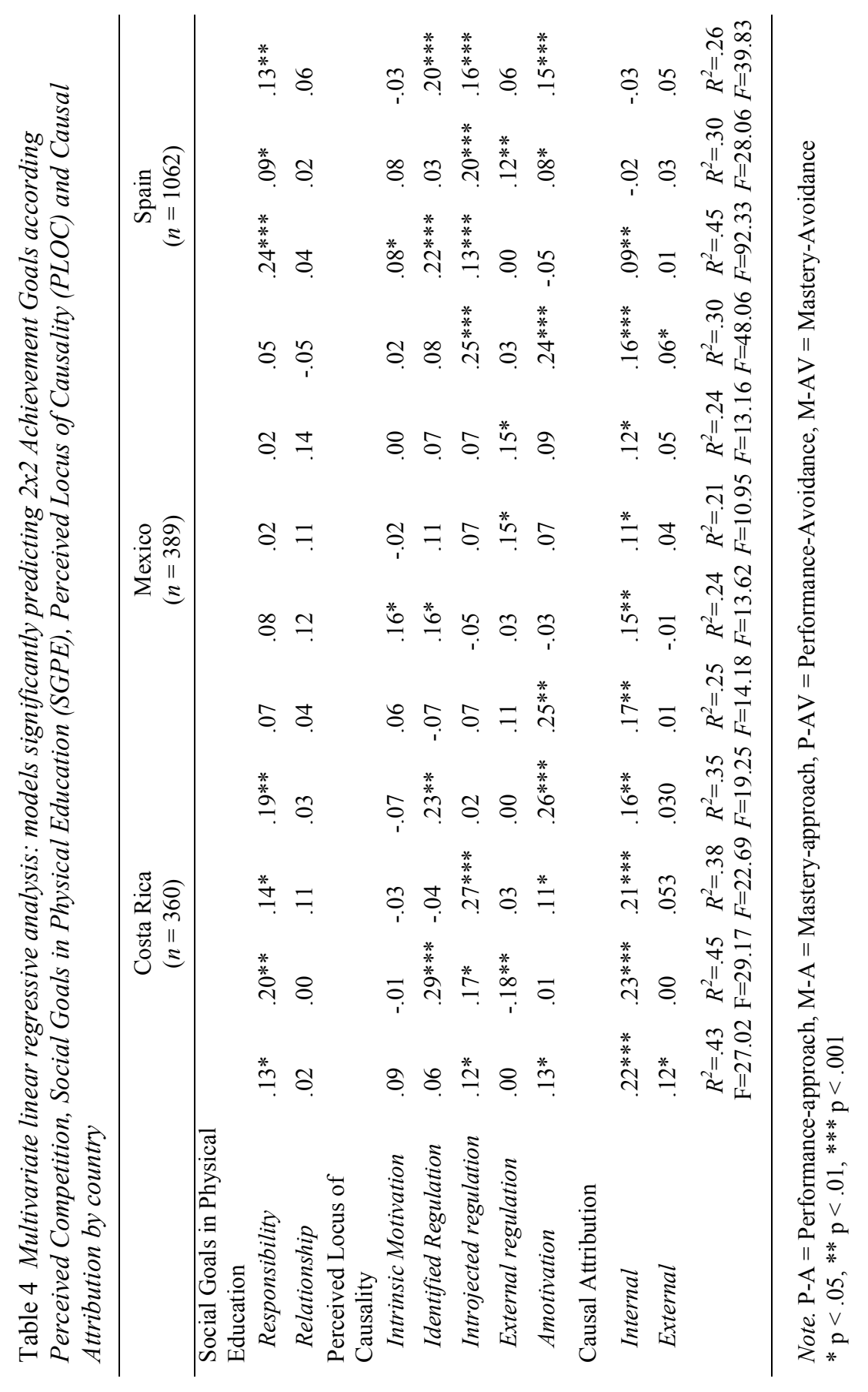


ance). In Mexico it is predicted by high scores in intrinsic motivation, identified regulation and internal attributions (24\% of variance). In Spain it can be significantly predicted by high scores in responsibility, intrinsic motivation, introjected regulation, identified regulation and internal attributions ( $45 \%$ of variance). Both in the case of Costa Rica and Spain, performance-avoidance can be significantly predicted by high scores in responsibility, introjected regulation and amotivation, and by internal attributions in Costa Rica and external regulation in Spain (38\% of variance in Costa Rica and $30 \%$ in Spain). However, it can only be predicted by external regulation and internal attributions in Mexico (21\% of variance).

Finally, the mastery-avoidance models can be significantly predicted in Costa Rica and Spain by high scores in responsibility, identified regulation and amotivation and by internal attributions in Costa Rica and introjected regulation in Spain (35\% of variance in Costa Rica and 26\% in Spain). However, it can only be predicted by external regulation and internal attributions in Mexico ( $24 \%$ of variance).

\section{Discussion and Conclusions}

The aim of this study was to analyze how social goals, perceived locus of causality and causal attribution can predict goal orientations in PE students in Costa Rica, Spain and Mexico. Therefore, its importance lies in the predictive analysis of the tendency these three countries show in terms of Achievement Goals in PE using the 2x2 scale, which has still not been widely used in studies on secondary students (Cechini, González, Méndez-Giménez, \& Fernández-Río, 2011). If we take into account the results to date found in the literature, the study of the reasons and motives which lead students to become actively involved in class tasks is proved to be of relevance, given the impact this can have on students' lasting leisure time physical activity (Granero-Gallegos, Baena-Extremera, Pérez-Quero, Ortiz-Camacho, \& BrachoAmador, 2012; Lanuza, Ponce de León, Sanz, \& Valdemoros, 2012), this being the main object of school Physical Education.

This study obtained the highest mean scores in the mastery-approach subscale and the lowest ones in the performance-approach dimension. These results are similar for teenage students across the three countries studied, so it is safe to affirm that this is the overall tendency in the PE students analyzed (2168 students) and that it is in line with the work by Cecchini et al. (2011), Cervelló, Moreno, Martínez, Freís and Moya (2011), Méndez-Giménez et al. (2013) and Ruiz and Casado (2012). Furthermore, it is worth noting that the highest values in mastery-approach were obtained by Mexican students, while Spanish students scored the lowest in performance-approach. These results are likely to be the product of cultural differences, according to the studied sample.

Regarding social goals, the sample of two Latin American countries show the highest values in responsibility, whereas Spanish students of this study scored higher in relationship. Again, cultural differences seem to be behind the fact that Latin American students of this research feel more successful when they behave responsibly and base their behavior in the observance of social rules and roles. However, the data shows that Spanish students feel a stronger need to establish relationships and friendship with their classmates. In any case, the analyzed sample of the three countries show a tendency to 
medium and high scores in both dimensions, and research on PE has shown that this can have positive consequences in terms of effort, persistence, intrinsic motivation and satisfaction in students (Guan et al., 2006; Moreno-Murcia, Cervelló, Montero, Vera, \& García, 2012).

In terms of the perceived locus according to the studied sample, the overall tendency is for high scores in intrinsic motivation and lower scores in amotivation, Spain showing a higher level of self-determination. This data is in line with some recent studies showing high mean scores in intrinsic motivation and lower scores in amotivation (MorenoMurcia, Zomeño, Marín, Ruiz, \& Cervelló, 2013). Some of these studies show that high levels of intrinsic motivation translate into higher probabilities of students becoming physically active by themselves (Lim \& Wang, 2009), and even of doing more than three hours a week of physical activity outside the school (Granero-Gallegos et al., 2012).

In the case of causal attribution, and in line with Navas et al. (2008), students of this research take into account the classic causal attributions in achievement contexts when it comes to explaining their academic performance in PE classes. Moreover, in line with Navas et al. (2008) in their work with students from Valencia and also with Mascarenhas et al. (2005), who worked with Portuguese students, the data in this study indicates that the overall tendency across the three countries studied is higher scores in internal motivation factors (doing something which is not easy for others, effort, skills and ability).

Regarding the predictive analysis, it is worth noting that in the case of performanceapproach Elliot and Conroy(2005) carried out a study on sports and concluded that stimuli could be regarded as positive (surely due to the fact that it was situated in a competitive context based on victory), but that they could also distract the subject from executing the task in an optimum way and lead to negative outcomes. The latter is the case in this study, given that in the sample of the three countries studied the tendency is for this goal to be predicted by amotivation; it is in fact the case in Spanish students where the prediction relationship is stronger and more significant. Furthermore, there is also an overall tendency in the analyzed students towards internal factors of motivation (causal attribution) positively and significantly predicting performance-approach. It is worth highlighting that this relationship is stronger in Costa Rica, as seen in the results of the regressive analysis (Table 4) and supported by the correlation relationships (Table 3 ). In any case, it seems clear that students think that their efforts and capacity will make them achieve this goal. In fact, this internal causal attribution is an important predictor in all cases expect for mastery-approach. These results corroborate the findings in MéndezGiménez et al. (2013), which refer to the variety of profiles and the multiple goal perspectives, which students can adopt.

Furthermore, Valenzuela (2007) affirms that students establish a series of concepts expectations - which affect activity at the start of a new task depending on the attribution they award to the causes leading to effective or ineffective performances. Therefore, the explanations students give of the results they obtain in the execution of a task and their attributional classification has great impact on further learning.

With regard to performance-avoidance goals, the results of this paper show that 
they are predicted in a positive and significant way in Costa Rican and Spanish students mainly by introjected regulation; responsibility and amotivation goals also predict performance-avoidance though the relationship is lower. These students' motivation analyzed would be to avoid failure and avoid looking incompetent in the eyes of their classmates. However, the correlation of the responsibility subscale is striking. The data corroborates the study by Méndez-Giménez et al. (2013) given that the low level of achievement goals is related to low efforts, social relationship and high demotivation. According to Navas et al. (2008), performance-avoidance goals are deemed negative for those tasks requiring total concentration and mental disposition. In fact, the results obtained with these students show that this goal is predicted mainly by amotivation.

As to the $2 \times 2$ scale, empirical evidence shows that mastery-approach goals are related to more positive consequences (Moller \& Elliot, 2006) such as the intention of practicing sports, effort, autonomy and competence (Méndez-Giménez et al., 2013). The results obtained with 2168 students show that mastery-approach is predicted by introjected regulation and responsibility, especially in the case of Costa Rica and Spain. Furthermore, the mastery-approach goal is predicted by internal motivation factors in all analyzed sample of the three countries, although the relationship is stronger in the Latin American countries. These results are in line with those found by Wang et al. (2007) and Méndez-Giménez et al. (2013); both studies carried out a cluster analysis and proved that students with high achievement goals (high values in mastery-approach), showed high levels of self-determined motivation, relationships, joy, effort and PE practice and low lev- els of boredom and demotivation. Other studies (Elliot, 1999; Elliot \& Conroy, 2005; Moller \& Elliot, 2006) have also shown empirical evidence of mastery-approach goals being related to positive consequences in students. Elliot and McGregor (2001), for their part, state that mastery-avoidance goals seem to be more positive than performance-avoidance goals but less so than mastery-approach. The results in our study do not corroborate this, given that responsibility is also present in the prediction of mastery-avoidance and performance-avoidance in Costa Rica and Spain.

In terms of mastery-avoidance, the results with this sample show a similarity between both goals and across countries and they are predicted mainly by identified regulation, amotivation and the responsibility goal in Costa Rica and Spain. In the case of Mexico, the prediction relationship both from external regulation and internal causes is low. Following Anderman and Anderman (1999), these goals would correspond to students who attribute less importance to learning, with low levels of responsibility, of personal improvement intent and efforts. However, the results in our study do not corroborate these ideas and are more in line with MéndezGiménez et al. (2013) and Wang et al. (2007), studies in which the mastery goals profile included high levels of mastery-avoidance. In terms of Physical Education, when it comes to promoting positive behaviors in class, studies show that mastery-avoidance goals seem to be more suitable than performance-avoidance goals but less so than mastery-approach (Elliot \& McGregor, 2001). In our case, those differences are not so clear.

To conclude, the contribution of this study to the specialized literature should be highlighted; it shows overall tendencies across a 
sample from the three different countries in relation to scales so far not widely used in PE and which should be further studied. In view of this, the role of internal causal attribution as a predictor of achievement goals approach is worth noting. This should be read as a clue helping address topics and organization in PE classes, given the fact that students seem to respond to tasks involving efforts, skills and abilities rather than exclusively to tasks focused on merely recreational and entertainment activities, tasks which award attendance and participation and lacking clear objectives on which students can focus their efforts. Tasks with clear accessible goals are also necessary but they should involve and value students' efforts to achieve them. In this regard, climates in which students can clearly see what they need to do and thus focus their efforts should be promoted. The role of responsibility and relationships with peers in secondary classrooms should also be highlighted in view of the high values found across the three countries and the role of responsibility, as a predictor of mastery activities should also be underscored. In this regard, Moreno et al. (2012) recently found that this dimension is a predictor of students' efforts and there is another study (Moreno-Murcia, Huéscar, \& Cervelló, 2012), which shows that it has an impact on students' intentions to continue practicing physical and sports activity.

Received March 20, 2015

\section{References}

Ames, C. (1992). Achievement goals, motivational climate, and motivational processes. In G. Roberts (Ed.), Motivation in sport and exercise. Champaign, IL: Human Kinetics.

Anderman, L. H., \& Anderman, E. M. (1999). Social predictors of changes in students' achieve- ment goal orientations. Contemporary Educational Psychology, 25, 21-37.

Bollen, K. A., \& Long, J. (1994). Testing structural equation models. Newbury Park, CA: Sage.

Carretero-Dios, H., \& Pérez, C. (2005). Normas para el desarrollo y revisión de estudios instrumentales. International Journal of Clinical and Health Psychology, 5, 521-551.

Cecchini, J. A., González, C., Méndez-Giménez, A., \& Fernández-Río, J. (2011). Achievement goals, social goals, and motivational regulations in physical education settings. Psicothema, 23(1), 55-57.

Cervelló, E. M., Moreno, J. A., Martínez, C., Freís, R., \& Moya, M. (2011). El papel del clima motivacional, la relación con los demás, y la orientación de metas en la predicción del flow disposicional en educación física. Revista de Psicología del Deporte, 20(1), 165-178.

Cervelló, E., \& Santos-Rosa, F. J. (2000). Motivación en las clases de Educación Física: Un estudio de la perspectiva de las metas de logro en el contexto educativo. Revista de Psicología del Deporte, 9(1-2), 51-70.

Chen, A. (2001). A theoretical conceptualization for motivation research in physical education: An integrated perspective. Quest, 53, 35-38.

Deci, E. L., \& Ryan, R. M. (1985). Intrinsic motivation and self-determination in human behaviour. New York: Plenum.

Deci, E. L., \& Ryan, R. M. (2000). The "what" and "why" of goal pursuits: Human needs and the self-determination of behaviour. Psychological Inquiry, 11, 227-268.

Dweck, C. S. (1986). Motivational processes affecting learning. The American Psychologist, 41, 1040-1048.

Elliot, A. J. (1999). Approach and avoidance motivation and achievement goals. Educational Psychologist, 34, 169-189.

Elliot, A. J., \& Conroy, D. E. (2005). Beyond the dichotomous model of achievement goals in sport and exercise psychology. Sport and Exercise Psychology Review, 1(1), 17-25.

Elliot, A. J., \& McGregor, H. A. (2001). A 2x2 achievement goal framework. Journal of Personality and Social Psychology, 80, 501-519.

Goudas, M., Biddle, S., \& Fox, K. (1994). Perceived locus of causality, goal orientations, and perceived competence in school physical-education classes. British Journal of Educational Psychology, 64(3), 453-463.

Granero-Gallegos, A., Baena-Extremera, A., PérezQuero, F. J., Ortiz-Camacho, M. M., \& Bracho- 
Amador, C. (2012). Analysis of motivational profiles of satisfaction and importance of physical education in high school adolescents. Journal of Sports Science and Medicine, 11, 614-623.

Guan, J., McBride, R. E., \& Xiang, P. (2006). Reliability and validity evidence for the Social Goal Scale-Physical Education (SGS-PE) in High School settings. Journal of Teaching in Physical Education, 25, 226-238.

Guan, J., Xiang, P., McBride, R., \& Bruene, A. (2006). Achievement goals, social goals and students' reported persistence and effort in high school physical education. Journal of Teaching in Physical Education, 25, 58-74.

Hair, J. F., Black, W. C., Babin, B. J., \& Anderson, R. E. (2009). Multivariate data analysis $\left(7^{\text {th }} \mathrm{ed}\right.$.) New York: Pearson Prentice Hall.

Hoyle, R. H. (1995). Structural equation modeling: Concepts, issues, and applications. Thousand Oaks, CA: Sage.

Hu, L., \& Bentler, P. M. (1999). Cutoff criteria for fit indexes in covariance structure analysis: Conventional criteria versus new alternatives. Structural Equation Modeling, 6, 1-55.

Kline, R. (1998). Principles and practice of structural equation modeling. New York: Guilford.

Lanuza, R., Ponce de León, A., Sanz, E., \& Valdemoros, M. A. (2012). La clase de educación física escolar como generadora de un ocio físicodeportivo. Retos. Nuevas tendencias en Educación Física, Deporte y Recreación, 22, 13-15.

Lim, B. S. C., \& Wang, C. K. J. (2009). Perceived autonomy support, behavioural regulations in physical education and physical activity intention. Psychology of Sport and Exercise, 10, 5260 .

Malico, P., Rosado, A., Cabrita, T., \& Lancho, J. L. (2010). Atribuciones causales en el deporte: Estudio sobre las diferencias entre la percepción de éxito y fracaso. Apunts, Educación Física y Deportes, 100(2), 47-55

Mascarenhas, S., Almeida, L., \& Barca, A. (2005) Impacto das habilidades escolares dos pais e do género dos alunos. Revista Portuguesa de Educação 18(1), 77-91.

Méndez-Giménez, A., Fernández-Río, J., Cecchini, J. A., \& González, C. (2013). Perfiles motivacionales y sus consecuencias en educación física. Un estudio complementario de metas de logro 2x2 y autodeterminación. Revista de Psicología del Deporte, 22(1), 29-38.

Moller, A. C., \& Elliot, A. J. (2006). The 2x2 achievement goal framework: An overview of empirical research. In A. Mittel (Ed.), Focus on educational psychology. New York: Nova Science Publishers, Inc.

Moreno-Murcia, J. A., Cervelló, G., Montero, C., Vera, J. A., \& García, T. (2012). Metas sociales, necesidades psicológicas básicas y motivación intrínseca como predoctores de la percepción de esfuerzo en las clases de educación física. Revista de Psicología del Deporte, 21(2), 215-221.

Moreno-Murcia, J. A., González-Cutre, D., \& Sicilia, A. (2008). Metas de logro 2x2 en estudiantes españoles de Educación Física $2 \times 2$. Revista de Educación, 347, 299-317.

Moreno-Murcia, J. A., Huéscar, E., \& Cervelló, G. (2012). Prediction of adolescents doing physical activity after completing secondary education. Spanish Journal of Psychology, 15(1), 90100 .

Moreno-Murcia, J. A., Zomeño, T., Marín, L. M., Ruiz, L. M., \& Cervelló, E. (2013). Percepción de la utilidad e importancia de la educación física según la motivación generada por el docente. Revista de Educación, 362, 380-401.

Moreno, J. A., González-Cutre, C., \& Chillón, M. (2009). Preliminary validation in Spanish of a scale designed to measure motivation in physical education classes: The Perceived Locus of Causality (PLOC) Scale. The Spanish Journal of Psychology, 12(1), 327-337.

Moreno, J. A., González-Cutre, D., \& Sicilia, A. (2007). Metas sociales en las clases de Educación Física. Análisis y Modificación de Conducta, 33, 351-368

Navas, L., Holgado, F. P., Soriano, J. A., \& Sampascual, G. (2008). El cuestionario de atribuciones para educación física: Análisis exploratorio y confirmatorio. Acción Psicológica, 5(2), 77-85.

Nicholls, J. G. (1989). The competitive ethos and democratic education. Cambridge. MASS: Harvard University Press.

Ruiz, G., \& Casado, R. (2012). Orientación motivacional en estudiantes de educación física pertenecientes al programa de cualificación profesional inicial (P.C.P.I.) y su contraste con alumnos de la E.S.O. AGON Internacional Journal of Sport Sciences, 2(1), 17-24.

Ryan, A. M., Hicks, L., \& Midgley, C. (1997). Social goals, academic goals and avoiding seeking help in the classroom. Journal of Early Adolescence, 17, 152-171.

Ryan, R. M., \& Deci, E. L. (2000). Self-determination theory and the facilitation of intrinsic mo- 
tivation. Social development and well-being. American Psychologist, 55, 68-78.

Telama, R., Yang, X., Viikari, J., Valimaki, I., Wanne, O., \& Raitakari, O. (2005). Physical activity from childhood to adulthood: A 21-year tracking study. American Journal of Preventive Medicine, 28 , 267-273.

Urdan, T. C., \& Maehr, M. L. (1995). Beyond a two-goal theory of motivation and achievement: A case for social goals. Review of Educational Research, 65, 213-243.

Valenzuela, J. (2007). Exigencia académica y atribución causal: ¿qué pasa con la atribución al esfuerzo cuando hay baja significativa en la exigencia académica? Educere, 11(37), 283287.

Vallerand, R. J., \& Bissonnette, R. (1992). Intrinsic, extrinsic, and amotivational styles as predictor of behaviour - a prospective - study. Journal of Personality, 60(3), 599-620.

Vallerand, R. J., \& Rousseau, F. L. (2001). Intrinsic and extrinsic motivation in sport and exercise.
A review using the hierarchical model of intrinsic. In R. M. Singer, H. A. Hausenblas, \& C. M. Janelle (Eds.), Handbook of Sport Psychology $\left(2^{\text {nd }}\right.$ ed., pp. 389-416). New York: Wiley \& Sons. Vílchez, M. P. (2013). Relación de la Educación Física con la práctica físico-deportiva de tiempo libre. Doctoral Thesis. University Católica of San Antonio. Murcia, España.

Wang, C. K. J., Biddle, S. J. H., \& Elliot, A. J. (2007).The $2 \times 2$ achievement goal framework in a physical education context. Psychology of Sport and Exercise, 8, 147-168.

Weiner, B. (1986). An attributional theory of achievement motivation and emotion. New York: Springer-Verlag.

Weiner, B. (1995). Judgments or responsibility. A foundation for a theory of social conduct. New York: Guilford Press.

Wentzel, K. R. (1991). Social competence at school: Relation between social responsibility and academic achievement. Review of Educational Research, 61, 1-24. 